Novi Sad

jemit@uns.ac.rs

\title{
ANALIZA POTREBA STUDENATA TEHNOLOŠKIH FAKULTETA U SRBIJI U NASTAVI ENGLESKOG JEZIKA ${ }^{1}$
}

\begin{abstract}
APSTRAKT
Predmet ovog rada je analiza potreba studenata tehnoloških fakulteta u Srbiji u nastavi engleskog jezika za oblast tehnološke i inženjerske struke. Kako procedura analize potreba objedinjava analizu jezika struke, analizu ciljne situacije, analizu trenutnog nivoa znanja polaznika kao i analizu nastavnog konteksta, u radu je prvo ispitana analiza trenutnog stanja u vezi sa upotrebom i nastavom engleskog jezika iz ugla kako studenata tako i predavača engleskog jezika na tehnološkim fakultetima u Srbiji, a zatim i analiza potreba u vezi sa upotrebom engleskog jezika zaposlenih inženjera tehnologije. Primenom ankete, kao metode sakupljanja podataka i upitnika kao mernog instrumenta, dobijeni su rezultati koji ukazuju na nedovoljnu zastupljenost engleskog jezika struke sa aspekta studenata i predavača, dok su zaposleni inženjeri ukazali na potrebu za čestim korišćenjem engleskog jezika za potrebe svog posla. U radu se kao pedagoške implikacije rada navodi: redefinisanje nastavnih planova i programa, mogućnost uvođenja stručnih jezičkih mikroveština u nastavu jezika struke kao i veći fond časova jezika struke na višim godinama studija.
\end{abstract}

Ključne reči: analiza potreba, engleski jezik nauke i tehnologije, akademske jezičke veštine, stručne jezičke veštine, izrada kursa EJS.

\section{TECHNOLOGY STUDENTS' NEEDS ANALYSIS IN EFL COURSES}

\section{ABSTRACT}

1 Rad je nastao na osnovu istraživanja koje je rađeno za potrebe doktorske disertacije na temu „Analiza potreba kao ključni aspekt u procesu izrade kursa engleskog jezika za oblast tehnološke i inženjerske struke" iste autorke. 
The subject of this paper is to analyze the needs of technology students in Serbia in English Serbia in English language teaching in the field of technology and engineering professions. Since needs analysis as a procedure covers numerous factors - target situation analysis, discourse analysis, present situation analysis and teaching context analysis, needs analysis in this paper is viewed from learners', teachers' and domain experts' point of view. In the first phase, we conducted present situation analysis on the English language use and teaching process from the point of view of technology students and English teachers. We concurrently conducted the needs analysis of the English language use from the point of view of employed technology engineers.

By using a survey as a method of data collection and questionnaire as a tool, the obtained results show poor frequency of the use of English for specific purposes in the teaching process from the point of view of students and English language teachers. The results from the employed technology engineers' point of view, on the other hand, show frequent use of the English language for professional purposes as well as the importance of English language competence for better work performance, especially emphasizing reading, communicative and writing skills for professional purposes. Pedagogical implications of the research are the following: redefine ESP syllabi, introduce specific, professionally oriented language skills in the teaching process and increase class hours for senior students.

Key words: needs analysis, English for science and technology, academic language skills, professional language skills, ESP course design.

\section{UVOD}

S obzirom na činjenicu da je cilj nastave stranog jezika struke osposobljavanje polaznika da se adekvatno služe stranim jezikom u okviru svoje buduće profesije, neophodno je da se predavači stranih jezika upute i informišu o specifičnim potrebama polaznika vezanih za njihovo buduće ili trenutno zanimanje. Potrebno je, dakle, utvrditi najčešće korišćene jezičke veštine, specifičnu terminologiju, odgovarajuće jezičke strukture, specifične žanrove, kao i osobine određenog stručnog diskursa. Kako bi se kreirao adekvatan plan i program, a u skladu sa tim izabrao adekvatan nastavni materijal i odgovarajuća metodologija, neophodno je izvršiti analizu potreba, koja se u literaturi spominje kao prvi korak u organizovanju nastave jezika struke (Robinson 1991; Basturkmen 2010, Flowerdew 2013). Ovaj zadatak najčešće je poveren nastavnicima i predavačima stranih jezika, odnosno metodičarima i lingvistima. 
Međutim, kako bi došli do pravog rešenja uzimajući u obzir sve zahteve koji se odnose na specifične jezičke potrebe svojih polaznika, nastavnici jezika struke vrlo često moraju uključiti različite izvore podataka, na prvom mestu same studente (polaznike kursa), kao i same predstavnike odgovarajuće struke - lekare, ekonomiste, inženjere, pravnike. tj. osobe koje jezik struke koriste u konkretnim situacijama za potrebe svog posla (Basturkmen 2010, Long 2005).

\section{ANALIZA POTREBA}

U literaturi metodike nastave stranog jezika struke, analiza potreba (eng. needs analysis) se definiše kao postupak koji podrazumeva prikupljanje relevantnih informacija, vezanih za specifičan jezik i jezičke veštine, potrebne za organizovanje nastave stranog jezika određene struke (Basturkmen 2010, Parkinson 2013, Flowerdew 2013). Tokom svog razvoja analiza potreba prošla je kroz nekoliko faza, te je s početka 80 -ih godina 20 . veka podrazumevala utvrđivanje komunikacionih potreba na osnovu rezultata analize komunikacije u ciljnim situacijama što će kasnije biti nazvano analizom ciljne situacije (Chambers 1980). Krajem 20. veka analiza potreba, pored analize ciljne situacije, uključuje i: lične informacije o polaznicima kursa (razlozi pohađanja, očekivanja, želje), analizu trenutne situacije (nivo trenutnog znanja i veština koji polaznici poseduju), nedostatke u znanju (razliku između trenutne i ciljne situacije), efikasne načine učenja jezika i veština (potrebe učenja), potreban vid komunikacije buduće struke polaznika (lingvistička analiza, analiza diskursa, analiza žanra), očekivanja od samog kursa kao i informacije o okruženju u kome će se kurs održavati (Dadley-Evans and St John 1998: 125). U poslednjoj fazi razvoja s početka 21. veka, analiza potreba se smatra prvim korakom koji prethodi procesu izrade kursa, na osnovu koga se utvrđuju tačni ciljevi nastave, izrađuje plan i program, vrši izbor ili se kreira adekvatan nastavni materijal, određuje metodologija i naposletku vrši evaluacija kursa (Basturkmen 2010: 17). Preciznije rečeno, prema Basturkmenovoj, proces analize potreba podrazumeva sledeće aktivnosti (Basturkmen 2010: 19):

- Analizu ciljne situacije (identifikacija zadataka, aktivnosti i jezičkih veština u kojima će polaznici koristiti engleski jezik i šta bi sve polaznici trebalo da znaju);

- Analizu diskursa (opis jezika koji se koristi u spomenutim situacijama);

- Analizu trenutne situacije (utvrđivanje šta polaznici znaju, a šta ne i šta mogu ili ne mogu da urade u odnosu na zahteve ciljne situacije); 
- Analizu faktora polaznika (motivacija polaznika i njihova percepcija potreba);

- Analizu nastavnog konteksta (faktori koji se odnose na okruženje u kome će se kurs odvijati i razmatranje šta realno kurs i predavač mogu da ponude polaznicima).

Iz navedenih faktora vidimo da je sa razvojem nastave jezika struke u analizi potreba došlo do objedinjavanja analize jezika struke (analiza registra, diskursa i žanra), analize ciljnih potreba i trenutnog nivoa znanja polaznika kao i nastavnog konteksta. Ovakva analiza potreba svakako daje jednu kompletniju sliku, tj. snimanje situacije iz svih uglova gledanja (studenata - budućih tehnologa, predavača stranog jezika struke i stručnjaka iz određene naučne oblasti). Ovako obavljena analiza potreba biće korišćena i u eksperimentalnom delu ovog rada.

Sa ovakvom tezom o analizi potreba slaže se i Long, koji je u velikoj meri kritikovao planove i programe koji su bazirani na pojmovno-funkcionalnim potrebama koji se oslanjaju samo na intuiciju primenjenih lingvista i predavača engleskog jezika pre nego na specijaliste iz određene oblasti i same studente (Long 2005). Tako je nastao i pristup analizi potreba baziran na zadacima (eng. task-based needs analysis), koji je ukazao na važnost opisa posla, potrebnih zadataka i standarda obavljanja posla koje formulišu eksperti iz određene oblasti, pružajući tako mnogo pouzdanije izvore podataka nego što bi to uradili samo lingvisti i predavači stranog jezika.

S obzirom na to da svaka pojedinačna struka sadrži specifičan registar, diskurs i žanrove, a zatim i potrebne, tj. češće korišćene akademske i stručne jezičke veštine, u narednom delu ćemo detaljnije opisati akademske jezičke veštine engleskog jezika nauke i tehnologije (EJNT) kao i važnost saradnje nastavnika jezika i profesora stručnih predmeta u okviru koga je sprovedena analiza potreba u ovom radu.

\subsection{Akademske veštine i nastava engleskog jezika, nauke i tehnologije}

Kada je u pitanju podela engleskog jezika struke (EJS), značajno mesto $\mathrm{u}$ oblasti metodike nastave engleskog jezika svakako zauzima engleski jezik za akademske namene (EJAN), tj. nastava za studente na univerzitetima. Sa razvojem nauke, tehnologije i sve intenzivnije međunarodne komunikacije, iz ove oblasti nastave izdvojile su se dve zasebne grane - Engleski jezik za profesionalne namene (EJPN) (eng. English for Occupational / Professional Purposes) i već spomenuta oblast Engleski jezik za akademske namene (eng. English for Academic Purposes). Međutim, mnoge profesije kao što su lekari 
i inženjeri mogu se svrstati u obe grupe (Jordan 1997: 4). Tako bi obuka za inženjere tehnologije koji su zaposleni u laboratorijama, fabrikama i pogonima podučavala buduće tehnologe za interakciju tehnolog-majstor, pisanje različitih vrsta izveštaja i zahteva, telefonski razgovori, poslovna komunikacija, što pripada oblasti EJPN. Sa druge strane, inženjeri tehnologije koji su zaposleni na fakultetima i naučnim institutima bi se obučavali za pisanje naučnih radova, apstrakata, čitanje stručne literature i praćenje savremenih trendova iz određene oblasti što pripada domenu EJAN. Nesumnjivo je da se nastava engleskog jezika na fakultetima dovodi u vezu sa ovladavanjem jezičkim znanjem i jezičkim veštinama koje se koriste u formalnom akademskom okruženju. Stoga se termin „akademske veštine“ (eng. study skills) najčešće u literaturi koristi za ovaj tip nastave stranog jezika. Iako neki autori smatraju da ovaj termin podrazumeva pre mehaničke veštine potrebne za studiranje, npr. navođenje literature, fusnota, citiranje i sl. (Robinson 1991), u novijoj literaturi ovaj termin je šire shvaćen i pored spomenutih veština podrazumeva četiri osnovne jezičke veštine (čitanje, slušanje, pisanje i govorenje), kao i niz drugih veština i podveština potrebnih za studiranje (Jordan 1997: 7, Dudley-Evans and St John 1998).

Receptivna jezička veština slušanja u akademskom okruženju prevashodno se odnosi na razumevanje predavanja i vežbi i pisanje beležaka pri čemu se pod razumevanjem podrazumeva razlikovanje glavne od sporednih ideja, razlikovanje iznošenja opštih činjenica od nečijih ideja i mišljenja, kao i razlikovanje ideja i pojmova od konkretnih primera. Kada veštinu slušanja, tj. razumevanja sagledavamo sa aspekta budućih tehnologa van akademskog okruženja, treba naglasiti važnost poznavanja stručnog vokabulara iz oblasti tehnologije i inženjerstva, kako bi zaposleni uspešno i precizno obavljali svakodnevnu komunikaciju, kao i razumevanje sagovornika u telefonskom razgovoru (McDonough 2010).

Veština čitanja kao druga receptivna veština smatra se podjednako važnom budućim tehnolozima, zaposlenim i u akademskom i u profesionalnom okruženju. Kod veštine čitanja važno je napomenuti da postoji razlika između jezika i forme, tj. žanra najčešće korišćenih pisanih formi u akademskom okruženju, kao npr. naučnih radova, knjiga, magistarskih teza, doktorskih disertacija i s druge strane, priručnika, uputstava, izveštaja, poslovne prepiske koji se koriste u profesionalno-tehnološkom okruženju. Žanrovska analiza pomaže polaznicima da prvo kao čitaoci, a kasnije i kao autori radova nauče osnovne elemente potrebne pisane forme (Hirvela 2004). Autori Maršal i Gilmor takođe ukazuju da predavači stranog jezika struke ne treba samo da zahtevaju od studenata da nauče spisak naučnog i tehničkog vokabulara već da stručne termine 
obrađuju u kontekstu i strukturnom odnosu u kojima stručne reči dobijaju svoje značenje (Marshall and Gilmour 1993: 75).

Što se tiče produktivnih jezičkih veština govora i pisanja, istraživanja su pokazala da u razvoj jezičke veštine govora moraju biti uključeni i opšti i stručni jezički konteksti, tj. akademski i profesionalni, pošto veliki broj inženjera, najpre ima potrebu za akademskim kontekstom za vreme studiranja, a zatim se potrebe fokusiraju na određenu profesiju ili oblast (Cheng and Mok 2008, Kaewpet 2009). U akademskom okruženju treba spomenuti usmenu formu kao što je usmena prezentacija, koja se sastoji od uvođenja teme, predstavljanja centralnog dela kroz definisanje, opisivanje, podelu/e, upoređivanje, davanje primera, predstavljanje rezultata, sumiranje i izvođenje zaključaka. Sa aspekta stručnog jezičkog konteksta, treba spomenuti forme kao što su svakodnevna poslovna komunikacija, razgovori telefonom, podnošenje izveštaja nakon izvršenog zadatka i sl. Kada su u pitanju profesije kao što su inženjeri, zaposleni u pogonima i fabrikama, kao i izvođači radova na gradilištima, istraživanja su pokazala da se gramatička tačnost pokazala manje važnom od sposobnosti tumačenja vizuelnih sredstava, npr. tumačenje dijagrama i slika.

Konačno, produktivna jezička veština jeste i pisanje koja je od velikog značaja kako za studente tako i za zaposlene. Neophodno je naučiti osnovne konvencije pisanja na engleskom jeziku, kako bi studenti imali mogućnost da učestvuju na međunarodnim konferencijama i postanu članovi međunarodne akademske zajednice, a zaposleni da postanu deo međunarodne profesionalne zajednice. Razvoj jezičke veštine pisanja podrazumeva učenje posebnih karakteristika akademskih formi pisanja (žanrova) poput naučnih radova, apstrakata, disertacija i stručnih formi pisanja poput elektronskog pisma, poslovnog pisma i inženjerskih izveštaja (Johns 2002, Hyland 2004). Svaka od spomenutih formi ima svoje delove kao što su uvod, metodologija istraživanja, opis problema/pojave, definicija, primeri, zaključak i tome slično. Pored karakteristika specifičnih formi pisanja, treba spomenuti važnost konciznog i jasnog stila, korišćenje adekvatnog vokabulara i gramatičkih oblika koji su tipični za naučne i stručne tekstove.

Ono što bi se moglo nazvati zajedničkom karakteristikom ovih veština jeste i činjenica da se one ne usvajaju instiktivno i po automatizmu, već se vremenom uče i postepeno razvijaju, stoga postoji potreba za njihovim podučavanjem kako izvornih govornika tako i učenika stranog jezika (Jordan 1997: 8). Pored toga, istraživanja ukazuju da su jezičke veštine uvek smeštene u određeni jezički kontekst i određenu naučnu ili stručnu zajednicu i tako čine jednu društvenu praksu (Lea and Street 1998). 
Kako bi nastava stranog jezika na fakultetu bila što uspešnija, u literaturi se preporučuje saradnja nastavnika stranog jezika i profesora stručnih predmeta kao bitan faktor EJS, jer se na ovaj način nastavnici stranog jezika mogu uputiti u precizne jezičke potrebe budućih stručnjaka iz različitih oblasti (Robinson 1989). Ovakva saradnja može biti realizovana kroz tri nivoa saradnje: kooperacija (eng. cooperation), kolaboracija (eng. collaboration) i timska nastava (eng. teamteaching) (Barron 1991: 174, Dudley-Evans and St John 1998: 42). Kooperacija, kao osnovni nivo saradnje, podrazumeva interesovanje profesora stranog jezika za jezičke potrebe svojih studenata i prikupljanje informacija u vezi sa stručnim predmetima koje studenti pohađaju. Kao drugi nivo saradnje, kolaboracija podrazumeva zajednički rad obe strane, profesora jezika i profesora stručnog predmeta sa ciljem da se studenti što bolje pripreme za zadatke koje podrazumeva kurs engleskog jezika. Poslednji nivo saradnje podrazumeva zapravo integraciju stranog jezika i stručnog predmeta na univerzitetskom nivou, gde se vidi stvaran zajednički rad dva profesora u učionici, što se vrlo retko ostvaruje u praksi (Đorović i Mirić 2011).

Pored usmerenosti nastave jezika na određene jezičke veštine i pomenute saradnje nastavnika stranog jezika i profesora stručnih predmeta važnu ulogu u kreiranju kurseva ima svakako analiza potreba, što je predmet istraživanja ovog rada.

\section{METODOLOGIJA ISTRAŽIVANJA}

Kako je predmet ovog rada analiza potreba koja obuhvata analizu jezika struke, analizu ciljne situacije, analizu trenutnog nivoa znanja polaznika kao i analizu nastavnog konteksta (Basturkmen 2010: 19), analiza potreba će u ovom radu biti sagledana iz svih pomenutih aspekata. S tim u vezi će i cilj ovog rada biti raščlanjen na tri glavna cilja:

- Analiza trenutnog stanja u vezi sa upotrebom i nastavom engleskog jezika struke sa aspekta studenata tehnoloških fakulteta u Srbiji;

- Analiza trenutnog stanja u nastavi engleskog jezika struke sa aspekta predavača engleskog jezika na tehnološkim fakultetima u Srbiji;

- Analiza potreba u vezi sa upotrebom engleskog jezika zaposlenih inženjera tehnologije.

Oslanjajući se na postavljene ciljeve istraživanja, u ovom radu polazimo od tri hipoteze: 
H1. Pretpostavlja se da će analiza stanja pokazati da se na tehnološkim fakultetima u Republici Srbiji nedovoljno radi engleski jezik struke i da ga studenti nedovoljno koriste.

H2. Pretpostavlja se da će analiza potreba pokazati da zaposleni tehnolozi, engleski jezik struke koriste u velikoj meri za potrebe svog posla i da nivo znanja engleskog jezika struke u velikoj meri utiče na uspešnost u poslu.

H3. Pretpostavlja se da analiza stanja i analiza potreba neće biti kompatibilne.

\subsection{Metode sakupljanja podataka i merni instrumenti}

Metoda sakupljanja podataka korišćena za potrebe ovog istraživanja je anketa (eng. survey), a kao merni instrument korišćen je upitnik (eng. questionnaire). Tip upitnika koji je korišćen u ovom istraživanju bio je zatvorenog tipa, sa mogućnošću da ispitanici (profesori i zaposleni) na pojedina pitanja daju pored ponuđenih i svoj lični odgovor, te bi po tome upitnik mogao preciznije da se podvede pod kombinovani tip. Pošto smo u istraživanju imali tri grupe ispitanika (studente, profesore engleskog jezika i zaposlene inženjere tehnologije), korišćena su tri upitnika za čiju izradu su upotrebljene informacije i smernice iz tri izvora: 1) upitnik koji je korišćen za analizu potreba studenata petrohemijskog inženjerstva (Al-Tamimi and Shuib 2010); 2) upitnik koji je korišćen za izradu kursa EJS za veštinu pisanja za inženjere u jednoj saudijskoj kompaniji (Abu-Rizaizah 2005) i 3) spisak akademskih veština po uzoru na Džordana (Jordan 1997: 7-8).

\section{Upitnik za studente}

Upitnik za studente je u svoja prva tri pitanja imao za cilj da pruži opšte informacije o ispitanicima: pol, godine starosti i dužina učenja engleskog jezika. Ostalih jedanaest pitanja su imala za cilj da ispitaju sledeće nezavisne varijable i sva pitanja su bila zatvorenog tipa:

- Učestalost korišćenja engleskog jezika za potrebe studiranja;

- Stav prema važnosti učenja engleskog jezika za buduće zanimanje;

- Stav prema važnosti učenja engleskog jezika struke;

- Zastupljenost jezika struke u nastavi engleskog jezika na fakultetu;

- Najčešći problemi pri upotrebi engleskog jezika (gramatika, stručni vokabular, određeni žanrovi, pismeno i usmeno izražavanje). 


\section{Upitnik za profesore engleskog jezika}

Upitnik za profesore engleskog jezika je sadržao 9 pitanja zatvorenog tipa i 3 pitanja otvorenog tipa. Prva četiri pitanja su imala za cilj da pruže opšte informacije o ispitanicima: pol, godine starosti, zvanje i uža naučna oblast. Preostalih pet pitanja zatvorenog tipa i tri pitanja otvorenog tipa su imala za cilj da ispitaju sledeće nezavisne varijable:

- Procena usmerenosti nastave engleskog jezika prema jeziku struke, odnosno opštem engleskom jeziku;

- Procena zastupljenosti specifičnih jezičkih veština;

- Učestalost korišćenja audio-vizuelnih i drugih nastavnih sredstava;

- Učestalost korišćenja metode simulacije buduće profesije studenata na engleskom jeziku;

- Mišljenje ispitanika o trenutnom stanju i problemima u nastavi engleskog jezika struke i mogućnostima njene modifikacije.

\section{Upitnik za zaposlene inženjere tehnologije}

Upitnik za zaposlene inženjere tehnologije je sadržao 14 pitanja, od koji su prvih šest pitanja ispitivala opšte informacije o ispitanicima: pol, godine starosti, radno mesto, uža naučna oblast, dužina i mesto učenja engleskog jezika. Ostalih osam pitanja imala su za cilj da ispitaju sledeće nezavisne varijable i sva pitanja su bila zatvorenog tipa:

- Učestalost korišćenja engleskog jezika za potrebe posla;

- Učestalost korišćenja engleskog jezika struke za potrebe posla;

- Stav prema važnosti znanja engleskog jezika radi uspešnijeg obavljanja posla;

- Procena zastupljenosti korišćenja specifičnih jezičkih veština u okviru struke;

- Procena zastupljenosti specifičnih žanrova u okviru jezičkih veština čitanja, pisanja, govora i slušanja.

\subsection{Uzorak}

Kako se u kvantitativnim istraživanjima najčešće koristi nasumičan uzorak (eng. probability sample) koji podrazumeva optimalan broj ispitanika na osnovu koga bi se iz dobijenih podataka mogli izvesti zaključci o celoj populaciji, za potrebe ovog istraživanja ispitano je ukupno 355 ispitanika (260 studenata prve godine tehnoloških fakulteta, 10 predavača engleskog jezika na ovim fakultetima i 85 zaposlenih inženjera tehnologije), smatrajući da je ovaj 
broj dovoljan da se na osnovu odabranog uzorka mogu doneti zaključci koji bi se mogli generalizovati. Uzorak ispitanih studenata podrazumeva 100 studenata Tehnološkog fakulteta u Novom Sadu, 80 studenata Tehnološko-metalurškog fakulteta u Beogradu i 80 studenata Tehnološkog fakulteta u Leskovcu. Uzorak od 10 predavača engleskog jezika, iako izgleda mali, jeste dovoljan jer na sva tri spomenuta fakulteta radi po jedan predavač engleskog jezika, pa je ispitano još preostalih sedam sa srodnih fakulteta (Fakultet tehničkih nauka u Novom Sadu i Prirodno-matematički fakultet u Novom Sadu) kako bi se dobila jedna šira slika o trenutnom stanju u nastavi engleskog jezika struke na fakultetu. Treći deo uzorka činili su zaposleni inženjeri tehnologije, ukupno njih $85, \mathrm{~s}$ tim da se vodilo računa da ispitanici budu zaposleni u različitim kompanijama (20 ispitanika sa Naučnog instituta za prehrambene tehnologije iz Novog Sada, 20 ispitanika su tehnolozi - profesori i asistenti, zaposleni na Tehnološkom fakultetu u Novom Sadu, 5 ispitanika su tehnolozi iz Beočinske fabrike cementa, 10 ispitanika su tehnolozi zaposleni u Tarketu i Sintelonu iz Bačke Palanke, 10 ispitanika iz Perutnine Ptuj - Topiko u Bačkoj Topoli, 20 ispitanika iz Neoplante Novi Sad, Alltecha iz Sente i Industrije mesa Štrand iz Novog Sada).

Sprovođenjem analize potreba sa ove tri grupe ispitanika ispoštovano je tri od pet ključnih izvora za odabir uzorka za analizu potreba u učenju stranog jezika (Long 2005: 25): 1) objavljena i neobjavljena literatura, 2) polaznici kursa (studenti), 3) profesori jezika i primenjeni lingvisti, 4) stručnjaci iz određene naučne oblasti, 5) kombinacija više izvora.

\subsection{Tok istraživanja i način analize podataka}

Prvi korak u prikupljanju podataka u okviru kvantitativnog istraživanja bila je distribucija upitnika za sve tri grupe ispitanika (studenti, predavači engleskog jezika, zaposleni inženjeri tehnologije), koji je obavljen tokom prvog i drugog semestra u zavisnosti od toga u kom semestru se po planu i programu engleski jezik uči na fakultetu. Podaci koji su dobijeni na ovaj način, najpre su kodirani na skali od jedan do tri (trostepena Likertova skala), a zatim su uneti $\mathrm{u}$ originalnom obliku. Ovako kodirani podaci su obrađeni korišćenjem najpre deskriptivne metode, koja podrazumeva numeričko (procenat, srednja vrednost, standardna devijacija) i grafičko prikazivanje učestalosti pojedinačnih odgovora. Za statističku obradu kvantitativnih podataka iz upitnika korišćen je program Statistika 12.0, kojim su obrađivani dobijeni podaci iz sva tri upitnika. U skladu sa tim, rezultati svakog upitnika će biti predstavljeni prema postavljenim ciljevima, tj. nezavisnim varijablama koje su merene na ovaj način. Srednje vrednosti više posmatranih grupa su poređene metodom analize varijansi (ANOVA), odnosno 
t-testom u slučaju poređenja dve grupe. Raspodela posmatranih karakteristika (npr. pol) $\mathrm{u}$ datim grupama (npr. fakulteti) analizirana je neparametarskim hi-kvadrat testom. Svi rezultati će biti iskazani sa rizikom od $5 \%$, tj. vrednosti $\mathrm{p}<0,05$ ukazuju na statistički značajnu razliku među posmatranim vrednostima.

\section{ANALIZA REZULTATA I DISKUSIJA}

\subsection{Analiza rezultata iz upitnika za studente}

Upitnik za studente je za potrebe ovog istraživanja popunilo $260(\mathrm{~N}=260)$ studenata prve godine osnovnih akademskih studija na tehnološkim fakultetima u Srbiji (Novi Sad, Beograd i Leskovac), koji slušaju engleski jezik kao obavezan predmet na prvoj godini. U Novom Sadu se engleski jezik sluša u prvom semestru sa fondom od 3 časa, u Leskovcu u drugom semestru sa fondom od 4 časa, dok je u Beogradu engleski jezik dvosemestralni predmet sa fondom od 2 časa nedeljno.

Prva tri pitanja iz upitnika za studente odnosila su se na opšte informacije o ispitanicima - pol, godine starosti i dužinu učenja engleskog jezika. Na osnovu dobijenih rezultata, možemo zaključiti da je brojniji ženski pol $(70,8 \%)$ na sva tri tehnološka fakulteta u Srbiji i da je utvrđena statistički značajna razlika u brojnosti po polovima $(\mathrm{p}<0,0001)$.

Što se tiče starosne strukture studenata, možemo konstatovati da je većina studenata mlađa od 26 godina, što je iskazano sa visokim procentom od 94,62\% studenata u prvoj starosnoj grupi iz čega možemo zaključiti da su u anketi učestvovali ispitanici sličnih interesovanja i stavova.

Rezultati dužine učenja engleskog jezika pokazuju da je najveći broj studenata (58\%) učio engleski jezik u osnovnoj i srednjoj školi, njih $20 \%$ na fakultetu, a zatim $13 \%$ na privatnim časovima ili školama. Utvrđena je takođe statistički značajna razlika u raspodeli ovih odgovora ( $<<0,0001$, hi-kvadrat test), a ako gledamo po fakultetima redosled brojnosti po ponuđenim odgovorima je isti, jedino je u Leskovcu nešto veći broj studenata učio engleski jezik na privatnim časovima ili školi (29 studenata) nego na fakultetu (26 studenata). Iz ovakve raspodele procenata, možemo zaključiti da je više od polovine studenata engleski jezik učilo tokom osnovne i srednje škole što je vremenski period od 10 do 12 godina $^{2}$. Procenat od $20 \%$ studenata koji su dali odgovor pod d) na fakultetu

2 Jedan broj studenata počeo je da uči engleski jezik u prvom razredu, a deo u trećem razredu osnovne škole, što je zavisilo od osnovne škole i mesta. 
govori o broju studenata koji su u svoje dosadašnje obrazovanje uključivali i obrazovanje na fakultetu, od čega 3,46\% studenata nije u prethodnom školovanju imalo predmet Engleski jezik.

Četvrto i peto pitanje iz upitnika je imalo za cilj da utvrdi učestalost korišćenja engleskog jezika za potrebe studiranja što možemo precizno videti na grafikonima 1. i 2.

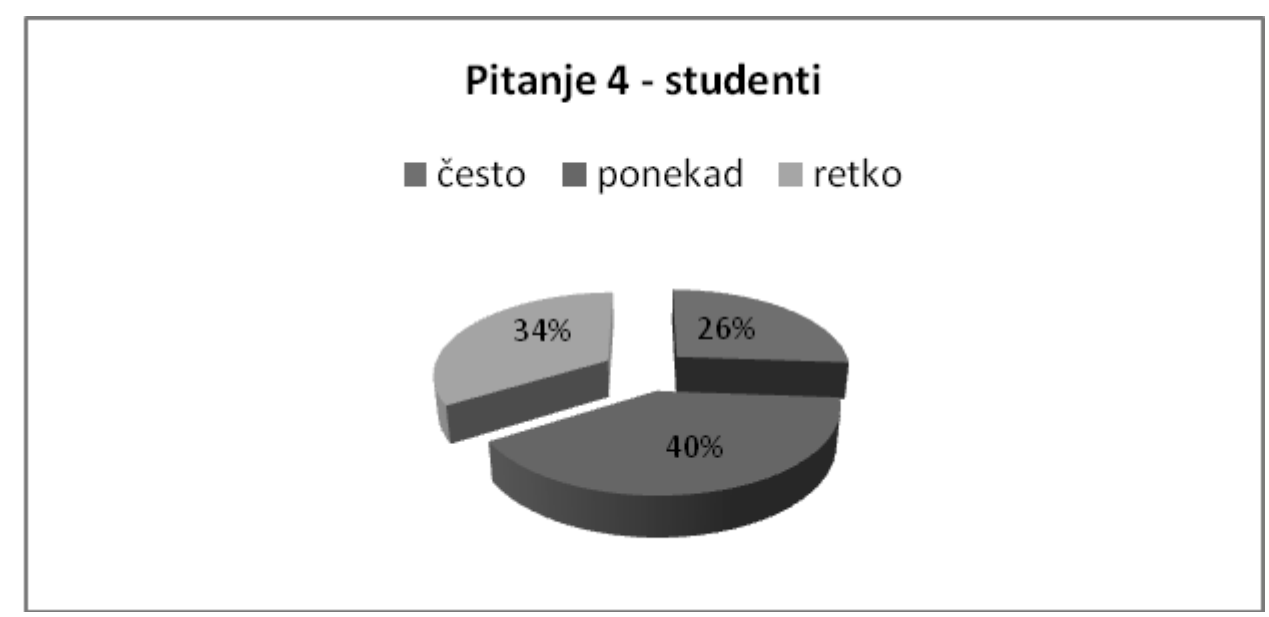

Grafikon 1. Pitanje 4 - studenti (učestalost koriščenja engleskog jezika za potrebe studiranja)

Dobijeni rezultati (Grafikon 1) pokazuju da je najfrekventniji odgovor studenata bio ponekad (jednom mesečno) (40\%) gde je potvrđena statistički značajna razlika u raspodeli odgovora neparametarskim hi-kvadrat testom $(\mathrm{p}=0,0234)$. Zatim su sledili odgovori retko (jednom u semestru) sa $34 \% \mathrm{i}$ odgovor često (jednom nedeljno) sa $26 \%$. Ovakva raspodela odgovora studenata bila je donekle i očekivana, s obzirom da se radi o studentima prve godine, kada se studenti tek upoznaju sa stručnim predmetima.

Postavljeni cilj učestalost korišćenja engleskog jezika za potrebe studiranja je preciznije ispitan u pitanju broj 5, gde su studenti imali mogućnost da zaokruže više odgovora i tako pokažu u kojim situacijama najčešće koriste engleski jezik. Rezultate ovog pitanja možemo videti na grafikonu 2. 


\section{Pitanje 5 - studenti}

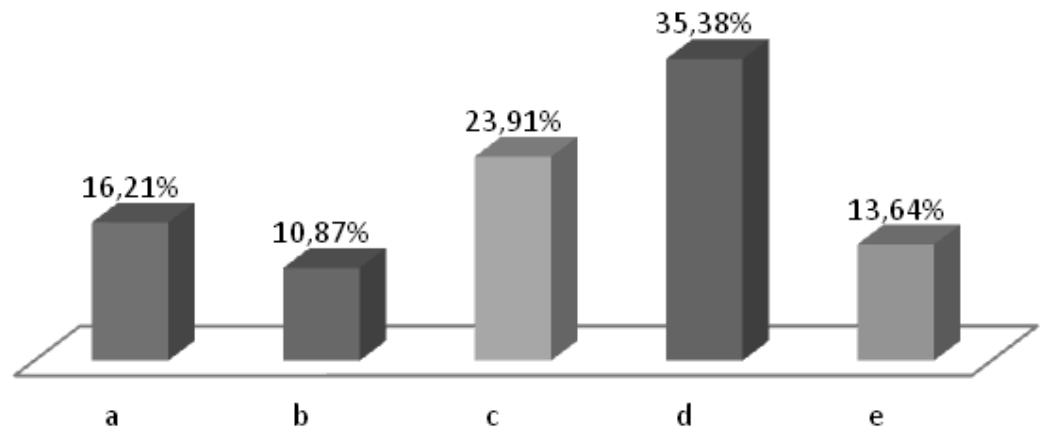

Grafikon 2. Pitanje 5 - studenti (situacije u kojima najčešće koriste engleski jezik)

a - slanje mejla, b - izrada domaćih zadataka, c - čitanje stručne literature (članci/knjige), d - Facebook/Tweeter/Skype, e - igranje igrica

Rezultati svih anketiranih studenata pokazuju da studenti engleski jezik najčešće koriste za potrebe društvenih mreža (Facebook, Tweeter, Skype) (35,4\%), zatim za čitanje stručne literature $(23,9 \%)$ i slanje mejla $(16,2 \%)$. Nije utvrđeno postojanje statistički značajne razlike u raspodeli odgovora po fakultetima $(\mathrm{p}=0,0578)$. Ovakvi rezultati pokazuju da engleski jezik studenti velikim delom koriste za zabavu, ali da svakako prepoznaju važnost engleskog jezika za potrebe svoje struke, pa tako i svog budućeg radnog mesta.

Kako su pitanja 6, 7, i 8 iz upitnika merila isti cilj - stav prema važnosti učenja engleskog jezika za buduće zanimanje na grafikonu 3. ćemo objedinjeno predstaviti dobijene rezultate. 


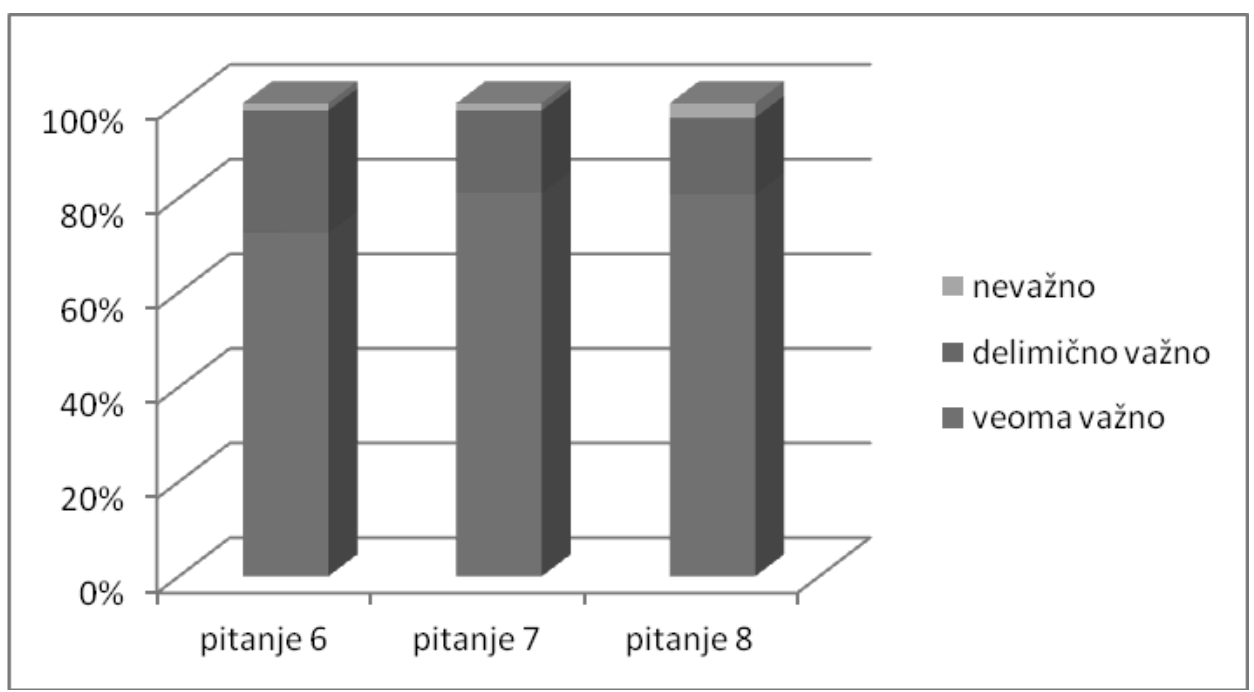

Grafikon 3. Pitanja 6, 7, 8- studenti (stav prema važnosti učenja engleskog jezika za buduće zanimanje)

Procentualno iskazano, preko $60 \%$ studenata ističe znanje engleskog jezika kao važan preduslov uspešnosti u svom budućem poslu (Grafikon 3). ANOVA analizom su poređene srednje vrednosti obrnuto kodirane Likertove skale i dobijena je statistički značajna jednakost $(\mathrm{p}=0,241)$ srednjih vrednosti dobijenih u pomenutim pitanjima. Ukupna srednja vrednost za objedinjena pitanja 6, 7. i 8. je blizu vrednosti 3 i iznosi 2,76 , što je potvrda pozitivnog stava studenata o važnosti učenja engleskog jezika u budućem pozivu.

Postavljeni cilj zastupljenost jezika struke u nastavi engleskog jezika na fakultetu je analiziran uporednim posmatranjem pitanja 9. i 10. što se može videti na grafikonu 4. 


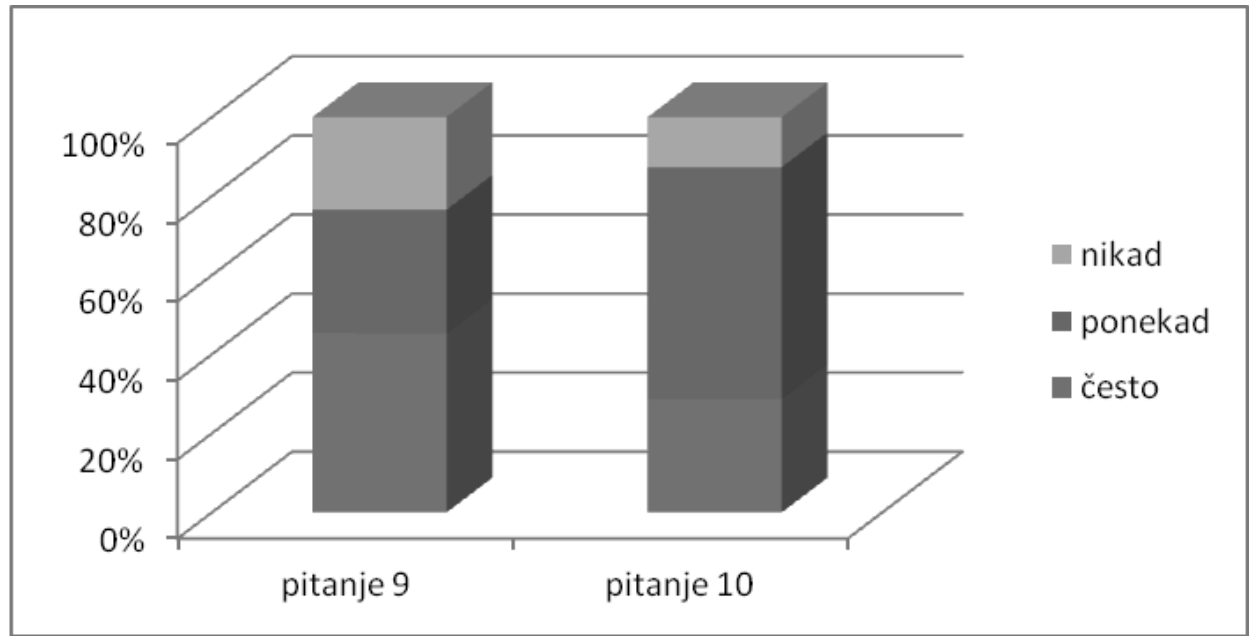

Grafikon 4. Pitanja 9. i 10 - studenti (zastupljenost jezika struke u nastavi engleskog jezika na fakultetu)

Srednje vrednosti u ovim pitanjima su poređene t-testom i nije ustanovljena statistički značajna razlika među njima $(\mathrm{p}=0,3606)$. Međutim, analizirajući raspodelu odgovora, neparametarskim hi-kvadrat testom, utvrđena je statistički značajna razlika $(\mathrm{p}<0,0001)$, što se jasno vidi i posmatrajući procentualne udele odgovora, gde je u 10. pitanju najfrekventniji odgovor ponekad, u odnosu na pitanje 9. gde je najčešći odgovor često (Grafikon 4). Sagledavajući oba pitanja koja su merila isti cilj zastupljenost jezika struke u nastavi engleskog jezika na fakultetu, možemo zaključiti da su rezultati pokazali da iako je jezik struke često zastupljen na fakultetima u Novom Sadu i Beogradu i nešto ređe na fakultetu u Leskovcu, zastupljenost stručnih žanrova i specifičnih jezičkih veština je samo povremena.

Pošto su cilj, stav prema važnosti učenja engleskog jezika struke, merila tri pitanja iz upitnika za studente $(11,12,13)$, dobijeni rezultati su upoređeni i objašnjeni, bez statističke analize, jer su u ovim pitanjima pored Likertove skale korišćena pitanja sa više opcija pa ih nije bilo moguće predstaviti kao jedinstveni skor (zbir ajtema).

Sagledavajući dobijene rezultate 11, 12. i 13. pitanja koja su merila cilj stav studenata prema važnosti učenja jezika struke, možemo zaključiti da većina (74\%) studenata smatra da jezik struke treba da bude deo nastave engleskog jezika na fakultetu, dok samo $1 \%$ studenata smatra da je to nepotrebno. Kako bi ovaj cilj i praktično bio sproveden u praksi, studenti su se izjasnili da je potrebno 
da se engleski jezik uči više od jednog semestra na fakultetu. Najviše studenata smatra da bi engleski jezik trebalo učiti tokom prvog $(25,8 \%)$ i drugog semestra $(22,6 \%)$, ali je primetan broj i onih koji su pored prva dva semestra zaokružili i III i IV semestar (13,1\% i 12,2\%). Primetno je i to da $8,8 \%$ procenata studenata smatra da engleski jezik treba da se uči i u VIII semestru, kada se smatra da su studenti dobro ovladali tehnološkom strukom. Što se tiče stručnih jezičkih veština i znanja koje bi po mišljenju studenata trebalo da budu zastupljene u nastavi engleskog jezika na fakultetu, izdvojio se stručni vokabular sa $34 \%$, pisanje stručnih žanrova sa $21 \%$ (laboratorijski izveštaj, poslovno pismo, apstrakt), upotreba formalnog/naučnog stila sa $20 \%$, slušanje/čitanje stručnog teksta sa $14 \%$ i telefonski razgovori sa $9 \%$.

Cilj poslednjeg 14. pitanja u upitniku za studente bio je da odredi najčešće probleme pri upotrebi engleskog jezika (gramatika, stručni vokabular, određeni žanrovi, pismeno i usmeno izražavanje). Rezultati ovog pitanja prikazani su na grafikonu 5.

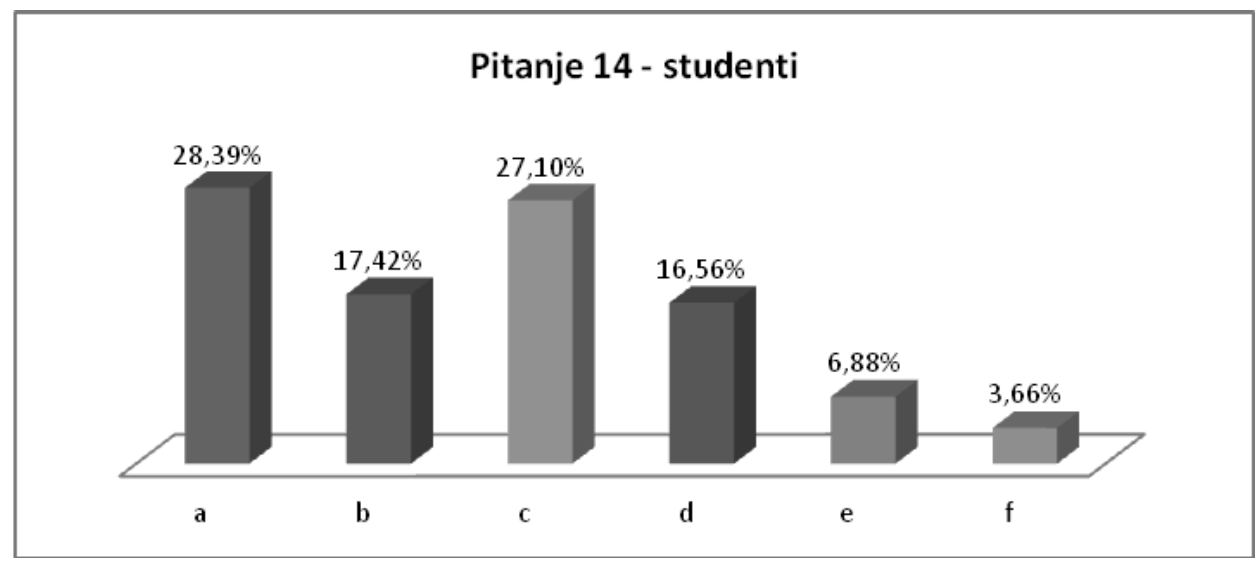

Grafikon 5. Pitanje 14 - studenti (najčešći problemi pri upotrebi engleskog jezika - gramatika, stručni vokabular, određeni žanrovi, pismeno i usmeno izražavanje)

Najviše studenata smatra da nailaze na probleme u gramatici $(28,39 \%)$ i usmenom izražavanju (27,10\%), zatim u proširivanju vokabulara $(17,42 \%)$ i pisanju $(16,56 \%)$ i na kraju na slušanje i razumevanje $(6,88 \%)$ i najmanje na čitanje i razumevanje (3,66\%, Grafikon 5). Neparametarskim testom je utvrđeno nepostojanje statistički značajne razlike u raspodeli odgovora po fakultetima $(\mathrm{p}=0,1338)$. 
Sagledavši sve dobijene rezultate upitnika za studente, možemo zaključiti da kod studenata postoji izuzetno visoka svest o važnosti engleskog jezika za njihovu buduću struku, ali i da postoje segmenti u nastavi koje bi trebalo modifikovati prema dobijenim rezultatima u smislu zastupljenosti jezika struke i stručnih žanrova i veština. Preciznije rečeno dobijen je rezultat delimične zastupljenosti jezika struke u nastavi engleskog jezika na fakultetu, s obzirom da srednja vrednost odgovora svih studenata iznosi 2,22 i najbliža je odgovoru ponekad iz upitnika. Pored toga, studenti su takođe uvideli problem nedovoljnog fonda časova engleskog jezika i njegove zastupljenosti samo u jednom semestru ili dva semestra. Dakle, dobijen je rezultat nedovoljne zastupljenosti engleskog jezika kao predmeta na fakultetu. Veoma važan rezultat za proces modifikovanja nastavnog procesa jeste i ukazivanje na probleme koje imaju u gramatici, stručnom vokabularu, ali i u usmenom i pismenom izražavanju. Dobijeni rezultati iz upitnika za studente potvrđuju polaznu hipotezu istraživanja, koja je pretpostavljala da će analiza trenutnog stanja u nastavi engleskog jezika na tehnološkim fakultetima pokazati nedovoljnu zastupljenost engleskog jezika struke (hipoteza 1).

\subsection{Analiza rezultata iz upitnika za zaposlene tehnologe}

Prva četiri pitanja iz upitnika za zaposlene inženjere tehnologije odnosila su se na opšte informacije o ispitanicima - pol, godine starosti, dužina i mesto učenja engleskog jezika. Od ukupno anketiranih $85(\mathrm{~N}=85)$ zaposlenih inženjera tehnologije bilo je $62 \%$ ispitanika ženskog i $38 \%$ ispitanika muškog pola. Anketirani inženjeri tehnologije su svrstani u tri starosne grupe: od 24 do 35 godina $(56,5 \%)$, od 36 do 45 godina $(29,4 \%)$ i preko 45 godina $(14,1 \%)$. Što se tiče mesta učenja engleskog jezika, najveći broj ispitanika je obeležio $(32,08 \%)$ nastavu engleskog jezika na fakultetu, nešto manje $(27,83 \%)$ u osnovnoj i srednjoj školi i $21,2 \%$ u privatnoj školi (časovima), dok 12,26\% ispitanika navodi da je samostalno učilo engleski jezik. Procentualni udeli od 5,19\% i 1,42\% se odnose na ispitanike koji su engleski jezik učili samo u osnovnoj i samo u srednjoj školi. Kada je u pitanju vremenski period učenja engleskog jezika, rezultati su pokazali da je više od polovine anketiranih (55,3\%) učilo jezik od 10 do 20 godina, 28,2\% ispitanika je učilo više od 20 godina, $12,94 \%$ ispitanika od 5 do 10 godina, dok je vrlo mali broj $(3,5 \%)$ njih učilo engleski jezik manje od 5 godina.

Pošto su 7. i 8. pitanje iz upitnika za zaposlene, merila dva srodna cilja: učestalost korišćenja engleskog jezika za potrebe svog posla (pitanje 7) $i$ učestalost korišćenja engleskog jezika struke za potrebe svog posla (pitanje 8) predstavićemo ih uporedo na grafikonu 6. 


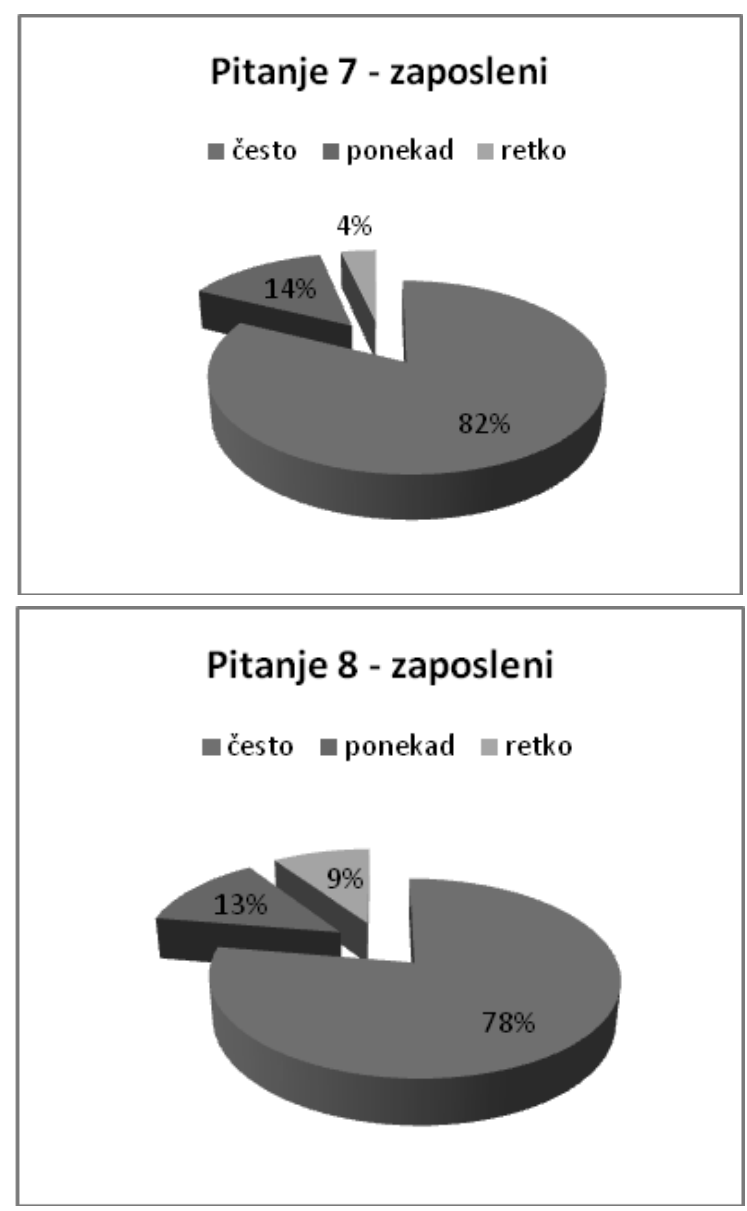

Grafikon 6. Pitanja 7. i 8 - zaposleni (učestalost korišćenja opšteg engleskog jezika i engleskog jezika struke za potrebe svog posla)

Najčešći dobijeni odgovor je često (kurziv) sa $82 \%$ za engleski jezik i $78 \%$ za engleski jezik struke. Koristeći hi-kvadrat test ustanovljeno je da nema statistički značajne razlike u raspodeli odgovora kada se porede pitanje 7. i 8 . $(\mathrm{p}=0,2961)$. Takođe, $\mathrm{t}$-testom su poređene i srednje vrednosti obrnuto kodirane Likertove skale i utvrđeno je da nema statistički značajne razlike među njima $(\mathrm{p}=0,2277)$. Srednje vrednosti $(2,79$ i 2,68$)$ su bliske maksimalnoj vrednosti 3 , što ukazuje na čestu upotrebu engleskog jezika i engleskog jezika struke u poslovnim aktivnostima kod anketiranih tehnologa. Dakle, možemo zaključiti da 
zaposleni tehnolozi često koriste i opšti engleski jezik i englesku jezik struke za potrebe svog posla.

Pitanje 9. je za cilj imalo da ispita stav prema važnosti znanja engleskog jezika radi uspešnijeg obavljanja posla, i čak $92 \%$ zaposlenih tehnologa smatra da znanje engleskog jezika utiče na uspešnost u poslu. Postoji veoma značajna razlika u brojnosti ispitanika koji su odgovorili na ponuđena pitanja $(\mathrm{p}<0,0001)$, a srednja vrednost obrnuto kodirane Likertove skale $(2,92)$ dodatno potvrđuje iskazane činjenice. Dakle, možemo zaključiti da ispitani tehnolozi (92\%) smatraju da je važno znanje engleskog jezika za uspešnije obavljanje posla.

Cilj desetog pitanja iz upitnika je procena zastupljenosti korišćenja specifičnih jezičkih veština u okviru struke. U ovom pitanju su ispitanici imali mogućnost da zaokruže više odgovora kako bi odredili zastupljenost korišćenja specifičnih jezičkih veština u okviru struke. Rezultati su pokazali da su se po zastupljenosti izdvojile jezičke veštine čitanja (34\%), pisanja (32\%) i usmene komunikacije (26\%) kao veoma potrebne za buduće tehnologe.

Poslednja četiri pitanja $(11,12,13$. i 14) iz upitnika imala su za cilj da odrede specifične žanrove $i$ mikroveštine koje se češće koriste u okviru jezičkih veština (čitanje, pisanje, usmena komunikacija, slušanje). U okviru jezičke veštine čitanja izdvojili su se žanrovi stručna literatura (46\%) i formalna pisma, mejlovi, dopisi (36\%) kao najpotrebniji. Što se tiče jezičke veštine pisanja izdvojili su se žanrovi formalna pisma/mejlovi (47\%) i naučni radovi/apstrakti (41\%) kao najčešće korišćeni žanrovi u radnom okruženju inženjera tehnologije. Najčešće korišćeni žanrovi koji su se izdvojili u okviru veštine govora su predavanja / izlaganja na naučnim skupovima (41\%), zatim debate, poslovni sastanci $(33 \%)$ i telefonski razgovori (26\%), a vrlo slični rezultati su dobijeni i za veštinu slušanja: predavanja / izlaganja na naučnim skupovima (47\%), a zatim debate / poslovni sastanci (37\%).

$\mathrm{Na}$ osnovu sagledanih ispitanih ciljeva upitnika za zaposlene inženjere tehnologije, možemo zaključiti da je potvrđena učestalost korišćenja engleskog jezika za poslovne potrebe inženjera i da je potvrđen stav o važnosti engleskog jezika radi uspešnijeg obavljanja posla, što potvrđuje i postavljenu hipotezu istraživanja (hipoteza 2) da će analiza potreba sa aspekta zaposlenih tehnologa ukazati da tehnolozi u velikoj meri koriste engleski jezik za potrebe svog posla i da nivo znanja engleskog jezika u velikoj meri utiče na uspešnost u poslu.

\subsection{Analiza rezultata iz upitnika za predavače engleskog jezika}

Svi anketirani predavači engleskog jezika $(\mathrm{N}=10)$ su ženskog pola i stariji od 35 godina, od čega je $40 \%$ bilo starije od 45 godina. 
Peto i šesto pitanje iz ovog upitnika (Grafikon 7) trebalo je da proceni usmerenost nastave engleskog jezika prema jeziku struke odnosno opštem engleskom jeziku, budući da je sam naziv predmeta na fakultetima engleski jezik i da se radi o predmetu sa prve godine studija.

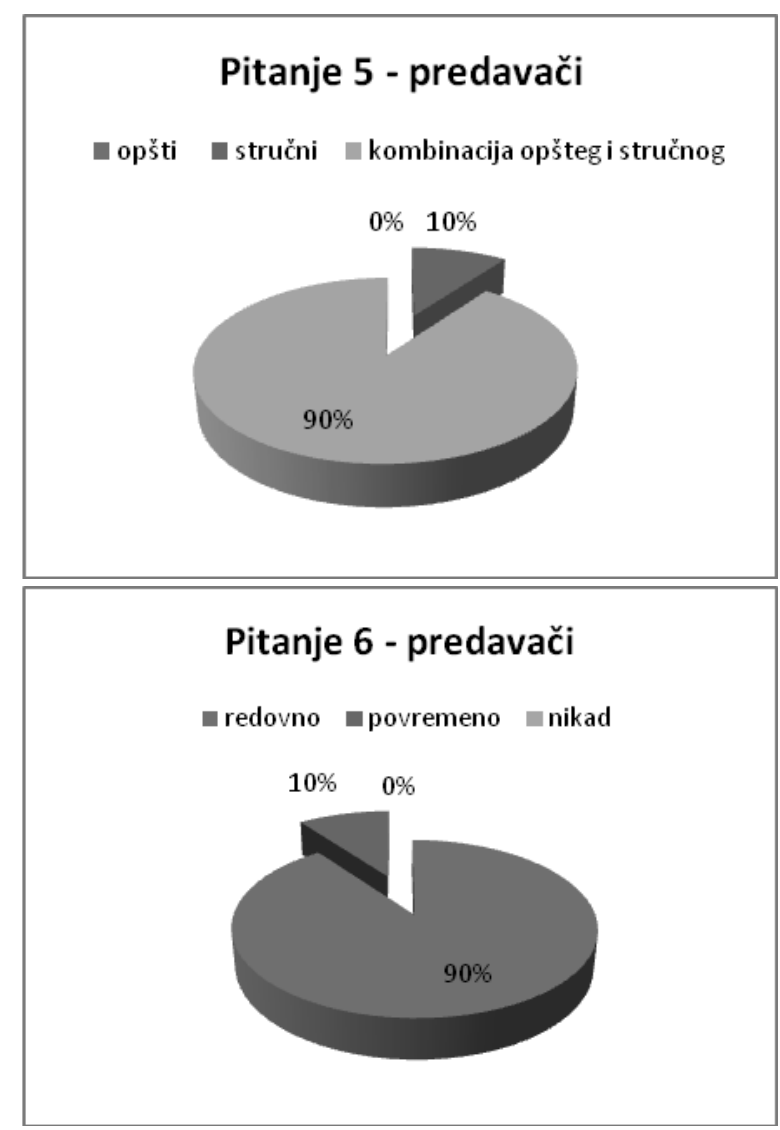

Grafikon 7. Pitanja 5,6-predavači (usmerenost nastave na jezik struke ili opšti i prisutnost jezika struke u okviru nastave)

Pitanje 5. pokazuje da $90 \%$ predavača engleskog jezika na tehnološkim i tehničkim fakultetima u Srbiji rade kombinaciju opšteg i stručnog engleskog jezika (u osnovi se radi opšti engleski jezik, dok se uz to obrađuje i engleski jezik struke). Iz odgovora ispitanika na pitanje 6. zaključuje se da predavači u velikoj meri (90\%) žele da uključe jezik struke u nastavu engleskog jezika, ali kao što će precizirati u pitanjima otvorenog tipa i dalje su veoma nezadovoljni njegovim udelom u nastavi na fakultetu. 
Procena zastupljenosti specifičnih jezičkih veština je ispitana u pitanju 7, gde je $60 \%$ ispitanika reklo da redovno obrađuju specifične jezičke veštine (mikroveštine - pisanje imejla, telefonski razgovor, poslovna komunikacija, pisanje izveštaja i apstrakta, čitanje stručne literature).

Pitanje 8. imalo je za cilj da ispita učestalost korišćenja metode simulacije buduće profesije studenata na engleskom jeziku, gde je dobijeno da $70 \%$ predavača povremeno, tj. vrlo retko radi simulacije. Ovakav rezultat pokazuje da predavači engleskog jezika, s obzirom da se engleski jezik predaje samo jedan ili dva semestra na fakultetu, ovu metodu nedovoljno uključuju u nastavu, što bi za buduće tehnologe bilo veoma korisno.

Učestalost korišćenja audio-vizuelnih $i$ drugih nastavnih sredstava je ispitana u pitanju 9 . Kako je $50 \%$ predavača reklo da povremeno koristi audio-vizuelna nastavna sredstva, a $40 \%$ da ih ne koristi, možemo reći da se na tehnološkim fakultetima u Republici Srbiji nedovoljno koriste moderna nastavna sredstva koja bi prevashodno bila korisna u domenu engleskog jezika struke.

Poslednja tri pitanja iz upitnika za predavače engleskog jezika su bila otvorenog tipa i imala su za cilj da predstave mišljenje predavača i preciznije ukažu na probleme u nastavi. Svih 10 ispitanika su ukazali na problem malog fonda časova i velikih grupa studenata. Pored toga, predavači ukazuju da je neophodno posvetiti više pažnje jeziku struke u nastavnom procesu, te bi preporuka za modifikaciju nastave bila da se na I godini studija radi opšti engleski jezik sa minimalnim fondom od 4 časa, a zatim da se engleski jezik struke radi na trećoj i četvrtoj godini kada su studenti dovoljno upoznati sa budućom strukom.

Sagledavajući sve ispitane ciljeve iz upitnika za predavače engleskog jezika možemo zaključiti da je na tehnološkim fakultetima u Srbiji jezik struke zastupljen samo kao segment opšteg engleskog jezika, pošto su rezultati pokazali da se u nastavi radi kombinacija jezika struke i opšteg engleskog jezika. Pored toga, možemo reći da je u nastavi delimično zastupljena upotreba specifičnih jezičkih veština (mikroveština). Rezultati su, takođe, pokazali nedovoljnu zastupljenost metode simulacije buduće profesije studenata, kao i korišćenje audio-vizuelnih i drugih nastavnih sredstava. Problem koji naglašavaju predavači engleskog jezika jeste mali fond časova i rad sa velikim grupama studenata. Sve navedeno govori u prilog postavljene hipoteze istraživanja da se na tehnološkim fakultetima u Republici Srbiji nedovoljno radi engleski jezik struke i da ga studenti nedovoljno koriste (hipoteza 1). 


\section{ZAKLJUČAK}

Zaključak koji se može izvesti na osnovu sprovedene analize stanja u nastavi engleskog jezika na tehnološkim fakultetima u Srbiji, jeste nedovoljna zastupljenost engleskog jezika struke i sa aspekta studenata i sa aspekta predavača. Pored toga, studenti pokazuju visoku svest o važnosti engleskog jezika za svoju buduću profesiju, dok zastupljenost jezika struke na fakultetu smatraju nedovoljnom, kao i dužinu učenja engleskog jezika kao predmeta na fakultetu (jedan ili dva semestra na I godini studija). Kao probleme na koje nailaze studenti navode: gramatiku, usmeno izražavanje i stručni vokabular. $\mathrm{S}$ druge strane, predavači engleskog jezika tvrde da je u nastavi na fakultetu zastupljena kombinacija opšteg engleskog jezika i jezika struke, ukazujući pri tome na problem malog fonda časova i velikih grupa studenata na fakultetu. $\mathrm{Na}$ ovaj način je potvrđena pretpostavka da se na tehnološkim fakultetima u Srbiji nedovoljno radi engleski jezik struke i da ga studenti nedovoljno koriste.

Zaključak koji sledi iz dobijenih rezultata analize potreba u vezi sa upotrebom engleskog jezika zaposlenih inženjera tehnologije jeste potreba za čestim korišćenjem engleskog jezika za potrebe svog posla. Zaposleni inženjeri posebno ukazuju na važnost engleskog jezika struke i jezičkih veština čitanja, pisanja i usmene komunikacije, a mikroveštine koje ističu su: čitanje stručne literature, pisanje formalnih pisama, naučnih radova i apstrakata, usmena izlaganja naučnih radova, predavanja i komunikacija na poslovnim sastancima. Na ovaj način je potvrđena i druga hipoteza ovog istraživanja, koja je pretpostavljala da će analiza potreba pokazati da zaposleni tehnolozi u velikoj meri koriste engleski jezik za potrebe svog posla, kao i da nivo znanja engleskog jezika struke utiče na uspešnost u poslu. Sagledavanjem zaključaka analize stanja i potreba, potvrđena je i treća hipoteza koja je pretpostavljala da analiza stanja i analiza potreba nisu u korelaciji.

Pedagoške implikacije istraživanja se prevashodno odnose na redefinisanje postojećih nastavnih planova i programa, a potom i na kreiranje kurseva jezika struke prema rezultatima dobijene analize potreba. Posebno bi bilo korisno uvođenje stručnih žanrova (laboratorijskog izveštaja, poslovnog pisma i apstrakta) u okviru veštine čitanja i pisanja, kao i usmena prezentacija radova na naučnim skupovima, debate, poslovni sastanci, telefonski razgovori u okviru veštine govora i slušanja. U metodološkom smislu bi češće trebalo koristiti metodu simulacije buduće profesije i korišćenje audio-vizuelnih nastavnih sredstava. Takođe bi trebalo razmotriti mogućnosti povećanja fonda časova engleskog jezika struke na višim godinama studija. 


\section{LITERATURA}

Abu-Rizaizah, S. (2005)."The Process of Designing an ESP Writing Course for Engineers in a Saudi Company". Arecls E-Journal 2: 58-64.

Al-Tamimi, A. S. and M. Shuib (2010)."Investigating the English Language Needs of Petroleum Engineering Students at Hadramout University of Science and Technology“. Asian ESP Journal 6 (1): 6-34. Pristupljeno 15.05.2014.

Basturkmen, H. (2010). Developing Courses in English for Specific Purposes. New York: Palgrave Macmillan.

Barron, C. (1991). "Material thoughts. ESP and culture“. English for Specific Purposes 10 (3): 173-187.

Chambers, F. (1980). "A Re-evaluation of needs analysis“. English for Speicific Purposes 1: 25-33.

Cheng, W. and E. Mok (2008). "Discourse processes and products: Land surveyors in Hong Kong“. English for Specific Purposes 2: 57-73.

Dudley-Evans, T. and M. J. St John (1998). Developments in ESP: a multidisciplinary approach. Cambridge: Cambridge University Press.

Đorović, D. i M. Mirić (2011). "Jezičke potrebe studenata nefilološke orijentacije sagledane kroz iskustva nastavnika“. Nastava i vaspitanje 60 (1): 23-35.

Flowerdew, L. (2013). "Needs Analysis and Curruculum Development in ESP", In: The Handbook of English for Specific Purposes, eds. Paltridge, B. and S. Starfield (Malden, MA: Wiley-Blackwell): 325-347.

Hyland, K. (2004). Disciplinary Discourses. Ann Arbor: University of Michigan Press.

Hirvela, A. (2004). Connecting Reading and Writing in Second Language Writing Instruction. Ann Arbor: University of Michigan Press.

Jordan, R. R. (1997). English for Academic Purposes. Cambridge: Cambridge University Press.

Kaewpet, C. (2009). "Communication needs of Thai civil engineering students." English for Specific Purposes 28: 266-278.

Johns, A. M. (ed.) (2002). Genre in the Classroom: Multiple Perspectives. Mahwah, New Jersay: Lawrence Erlbaum.

Lea, M. and B. Street (1998). "Student writing in higher education: an academic literacies approach". Studies in Higher Education 2: 157-172.

Long, M. H. (2005). "Methodological issues in learner needs analysis". In: Second language needs analysis, ed. M. H. Long (Cambridge: Cambridge University Press): 19-76. 
McDonough, J. (2010). "English for specific purposes: A survey review of current materials". ELT Journal 64: 462-477.

Marshall, S. and M. Gilmour (1993). "Lexical knowledge and reading comprehension in Papua New Guinea". English for Specific Purposes 12: 69-81.

Parkinson, J. (2013). English for Science and Technology, In The Handbook of English for Specific Purposes, eds. B. Paltridge and S. Starfield (Malden, MA: Wiley-Blackwell): (162-180).

Robinson, P, C. (1991). ESP Today: A Practitioner's Guide. New York: Prentice Hall.

Robinson, P. (1989). "An overview of English for specific purposes", In Working with language: a multidisciplinary consideration of language use in work contexts, eds. Coleman, H. and H. Coleman, (Berlin: Mouton de Gruyter): $395-428$. 


\author{
Jelena Jerković \\ University of Novi Sad \\ Faculty of Technology \\ Novi Sad \\ jemit@uns.ac.rs
}

\title{
TECHNOLOGY STUDENTS’ NEEDS ANALYSIS IN EFL COURSES
}

\section{Summary}

The topic of this paper is needs analysis as a necessary, first step before ESP course design. Since needs analysis as a procedure covers numerous factors - target situation analysis, discourse analysis, present situation analysis and teaching context analysis, needs analysis in this paper is viewed from learners', teachers' and domain experts' point of view. In the first phase, we conducted present situation analysis on the English language use and teaching process from the point of view of technology students and English teachers. We concurrently conducted the needs analysis of the English language use from the point of view of employed technology engineers.

By using a survey as a method of data collection and questionnaire as a tool, the obtained results show poor frequency of the use of English for specific purposes in the teaching process from the point of view of students and English language teachers. The results from the employed technology engineers' point of view, on the other hand, show frequent use of the English language for professional purposes as well as the importance of English language competence for better work performance, especially emphasizing reading, communicative and writing skills for professional purposes.

Pedagogical implications of the research are the following: redefine ESP syllabi, introduce specific, professionally oriented language skills in the teaching process and increase class hours for senior students.

Key words: needs analysis, English for science and technology, academic language skills, professional language skills, ESP course design.

Primljeno: 31. 3. 2016.

Prihvaćeno: 9. 5. 2016. 